\title{
Class, Youth, and Dirty Jobs: the working-class and post-war Britain in Pete Townshend's Quadrophenia
}

This chapter examines Pete Townshend's Quadrophenia (1973) and the way in which it depicts continuity and change in the lives of the British working-class in the period that the album documents (1964/5), the political milieu in which it was written (1972/3), and the legacy of the concept that was depicted in the screen version directed by Franc Roddam (1978/9). ${ }^{1}$ Quadrophenia was recorded and released in a fraught period of industrial militancy in Britain that had not been witnessed since the general strike of $1926 .{ }^{2}$ The album can be 'read' as both a social history of an element of youth culture in the mid-1960s, but also a reflection on contemporary anxieties relating to youth, class, race, and national identity in the period 1972/3. ${ }^{3}$ Similarly, the cinematic version of Quadrophenia was conceived and directed in 1978/9 in the months prior to and after Margaret Thatcher was swept to power, ushering in a long period of Conservative politics that economically, socially, and culturally reshaped British society. ${ }^{4}$ Quadrophenia is a significant historical source for 'reading' these pivotal years and providing a sense of how musicians and writers were both reflecting and dramatizing a sense of 'crisis', 'continuity', and 'change' in working-class Britain. ${ }^{5}$

Along with the novels and films of the English 'new wave' and contemporary sociological examinations of working-class communities and youth culture, Quadrophenia represents a classic slice of 'social realism', social history, and political commentary. It is a useful companion piece to Alan Sillitoe's Saturday Night and Sunday Morning (1958), which similarly centres on an anti-hero in the shape of Arthur Seaton who is alienated from the working-class world into which he was born. Quadrophenia's Jimmy was similarly conflicted regarding the cultural norms of the working-class family, the deference articulated by the post-war generation in the workplace, and the particular forms of politics that underpinned the post-war consensus. ${ }^{6}$ In substance and tone it offers a similarly nuanced view of youth culture and experiences that was first articulated by the director Karel Reiz in his ground breaking documentary We Are The Lambeth Boys (1959). ${ }^{7}$

Quadrophenia also provides similar insights to the ground breaking sociological research deployed in Young and Willmott's Family and Kinship in East London (1957). ${ }^{8}$ The politics of the album share the critiques of British society expressed by Anthony Sampson in his The Anatomy of Britain (1962) particular in relation to the rigidity of the class structure and the continuing dominance of social elites. ${ }^{9}$ The images that adorn the accompanying photo-essay by American photographer Ethan Russell complement Nell Dunn's ethnography of workingclass Battersea and the East End in novels such as Up the Junction (1963) and Poor Cow (1967). ${ }^{10}$ Battersea had a long tradition of labour politics, trade unionism, and attendant working-class cultures that remained a significant feature of the district in the 1960s-70s which can be seen and experienced in some of the tracks included on Quadrophenia, in the album's sleeve notes and in the overall imagery of the package. Aware of its roots in working-class localities across London and beyond, Townshend dedicated the finished album in 1973 to the teenagers from 'the Goldhawk Road ... Stevenage New Town and to the kids from the East End'.

Quadrophenia and the mod culture it depicts has often quite erroneously been compared to the presentation of affluence, social mobility, and mould-breaking youth cultures that are central to Colin MacInnes's much mythologized novel Absolute Beginners (1959). ${ }^{12}$ Yet in contrast to the conventional images of modernity, affluence, colour, and the mythology of the 'swinging sixties', Townshend's Quadrophenia and his British 'sixties' is a 'black and white world' of domestic drudgery, egg and chip breakfasts, dirty jobs, vandalism, cheap 
pornography, racism, the faded grandeur of seaside resorts, political alienation, class divisions and social deference. As such, Townshend's role as musician, writer, performer and commentator was more nuanced than some of his musical contemporaries and he shared with Ray Davies of the Kinks an acute sense of social observation and sense of working-class history and culture. ${ }^{13}$ Here was an attempt not to just capture the popular zeitgeist of 1964/5 and 1972/3, but a sophisticated attempt to understand the complexity of the British workingclass and the place of youth, fashion and popular music in its 'everyday life'.

\section{Popular music, the working-class, and the world of Pete Townshend ${ }^{14}$}

Townshend was a writer and performer who was not content crafting pop songs, but also wanted to provide narratives and analyses of youth culture and how it posed a challenge to the social conventions of British society. ${ }^{15}$ Doggett argues that Townshend was different from other performers of the 1960s in that he saw his 'role not to provide false hope, but to reflect the negativity felt by "the kids", ${ }^{16}$ For Townshend, "popular music had a serious purpose' and that was 'to defy post-war depression'. ${ }^{17}$ Like many of his musical contemporaries he was aware of the British class structure and his position within it that defined him as middle-class. He expressed his feelings to the New Musical Express in 1983 stressing that 'class, the attributes and consciousness ... has always been something that has evaded me'. ${ }^{18}$ Yet like John Lennon he was connected to the working-class through friendship, popular music, geographical proximity, and a fascination with its youth culture. ${ }^{19}$ As a songwriter he felt 'that the best pop songs always offered a space in the middle for the listener to inhabit'. ${ }^{20}$ This goes some way to explaining the 'cult status' of Quadrophenia and its lasting legacy. The narrative and the music 'spoke' to working-class youths of the 1970s and reflected their anxieties, aspirations, and complexities.

Townshend's parents were musicians and his father traversed the country as a member of the popular dance band the Squadronnaires. ${ }^{21}$ As a child in the mid-1950s, Townshend visited provincial theatres and holiday camps where a pre-war working-class culture now mixed with the contemporary sounds of rock ' $n$ ' roll. It was on the Isle of Man in 1957 where he attended a screening of Rock Around the Clock (1956) and 'nothing would ever be quite the same'. ${ }^{22}$ He followed what would become a fairly typical route into a music career and shared with his contemporaries a transformative experience of American rhythm and blues music. ${ }^{23} \mathrm{He}$ was a member of a skiffle band before establishing a successful recording and performing career as a member of The Who along with Roger Daltrey, John Entwistle and Keith Moon. ${ }^{24}$ Through his involvement in art school, the music industry and both the cosmopolitan and workingclass culture of London, Townshend would connect with a variety of characters that epitomised the British class system. ${ }^{25}$ According to Davey, Townshend was a member of the Campaign for Nuclear Disarmament and the Young Communist League and had played banjo as part of one of the Aldermaston marches against nuclear weapons. ${ }^{26}$ Denselow also claims that Townshend had also discussed politics with veteran leftists who were on the trad-jazz scene. ${ }^{27}$ Yet ultimately, he was more interested in youth culture as a political form of expression that operated outside of and could not be defined by particular ideological and organisational structures. This appears most starkly through the experiences of Jimmy in Quadrophenia. Jimmy struggles with the conventional expressions of identity such as trade unions and the strictures of the street and the broader working-class community.

Townshend wanted to articulate the feelings and emotions of working-class youth through song and performance and as a result his work with the Who was far more ambitious than the Beatles and the Rolling Stones in attempting to make sense of post-war Britain. According to Denselow, 'Townshend believed in his audiences, believed it was they and not the performers 
who were the real sixties idealists'. ${ }^{28}$ Songs such as 'I Can't Explain', 'Anyway, Anyhow, Anywhere', and 'My Generation', which charted in 1965 became mod anthems providing a soundtrack for a working-class youth who expressed an inarticulate, but keenly felt, sense of liberation and transgression in the coffee bar, dance hall, provincial theatre and coastal resort. ${ }^{29}$ For Townshend, The Who ... married their audience, they reflected them'. ${ }^{30}$ Mods present a particular image of Britain where some things changed and others remained the same. Yet within this image we see challenges to the boundaries of class, social convention and numerous examples of 'historic encounters' between white working-class youth, West Indian migrants and the sounds and struggles of black America. ${ }^{31}$ Quadrophenia goes beyond the inarticulateness of the three key Who singles noted above and attempts to convey a more detailed depiction of class as a lived experience that is punctuated by popular music, subcultural identity and social change.

The connection between Who fans and the band is expressed through testimony of mods from the 1960s. Jack Lyons witnessed the spectacle of the High Numbers during their residency at the Railway Hotel in Harrow and felt that here was a group that seemed to be speaking directly to him and his working-class friends. ${ }^{32}$ Mim Scala remembers it 'as a madhouse with hundreds of Vespa scooters outside'. ${ }^{33}$ Their manager Pete Meaden also got the group a residency at the Scene Club which was a working-class mod hangout. ${ }^{34}$ Through Quadrophenia, Townshend was to capture the mod phenomenon and the ways in which it reflected aspects of British society in 1964/5. To Marsh, Quadrophenia 'is a marvellous piece of social criticism, trying to place the public and private history of the 1960s into a context from which something more productive can be built'. ${ }^{35}$ To Davey, it 'is an audit of the successes and failure of the 1960s, the illusions of its youth cultures, and the failure of political projects to connect with popular aspirations' and 'provided a bleaker but more telling account of the sixties than cultural studies would soon produce'. ${ }^{36}$ Townshend himself claimed that in preparation for Quadrophenia he 'needed to look at the people I was writing about. This was almost Socialist writing for me'. ${ }^{37}$

The accompanying photo essay setting out the narrative of Quadrophenia captured the working-class aspects of mod subculture. ${ }^{38}$ Many of the youths used for the images were from the working-class council estates of Battersea, where the Who recorded the album. ${ }^{39}$ Photographer Ethan Russell recalled that "nothing much subtler than the Industrial Revolution really changes the face of England, and mod was something that lived and thrived in the same back streets of row houses ... to be found in Battersea in 1973, ${ }^{40}$ A precursor to this social realist approach is evident in the artwork that accompanied the release of the compilation album of Who singles in the form of Meaty Beaty Big and Bouncy (1971). The front cover features a section of slum housing with working-class kids hanging on the front steps of one of the dwellings with members of the band looking down at them through a broken window. This insight into working-class street kids is taken much further in the imagery and narrative of Quadrophenia. This was not really a swinging Britain, but a one that was bumping and grinding against poverty, inequality, and a rigid class structure. As such the album is relevant for unmasking the reality of the 'everyday life' of the workingclass in 1964/5 and 1972/3.

\section{Class, politics, and mod culture 1964/5}

Writers on youth culture have tended to view mod as either apolitical or fundamentally conservative. ${ }^{41}$ Yet it can be argued that the mod subculture to which Townshend attempted to become a spokesman was political in the sense that it posed a challenge to particular social boundaries that were a feature of 1960s Britain. Moreover, mod was an identity, subculture 
and movement that seemingly aimed to transcend class but in many ways was an expression of its resilience. ${ }^{42}$ The network of clubs, performers and consumers that created mod exhibited a sense of style and hedonism that had been a feature of pre-war working-class culture and had produced a particular critique of authority and convention expressed through fashion, music, and subcultural identity. ${ }^{43}$ Strands of such a pre-war working-class culture remain in Quadrophenia and mesh sometimes uneasily with the affluence, consumerism, and modernity of the 1960s.

Townshend's history of mod contained on Quadrophenia was based on events surrounding a concert by the Who at Brighton Aquarium on 29 March 1964, where he had witnessed the energy, excitement and violence of working-class youths who had embraced the culture as a source of individual and collective identity. ${ }^{44}$ The narrative documents the frustrations of a working-class youth, his connection and distance from the social milieu in which he was raised and ultimately his attempt to transcend the conventions of his home, workplace and locality through becoming a mod. Songs making up the seventeen tracks on the album such as 'Cut My Hair' (track 4), The Punk and the Godfather' (track 5), 'I'm One' (track 6), 'The Dirty Jobs' (track 7), 'Helpless Dancer' (track 8) and 'I’ve Had Enough' (track 10), provide examples of the limitations of social, organisational, and subcultural identities and how a working-class teenager simultaneously both feels a sense of both 'belonging' and 'distance' from them. Such experiences are contextualised in a period in which Britain is still recovering from the impact of the Second World War and significant social ruptures are transforming inner-city working-class communities.

Townshend aimed to create a 'working-class hero' that the fans of the Who could identify with. ${ }^{45}$ This would be somebody who reflected their desires, multiple identities, and imperfections. Aspects of working-class Britain are to the fore in Townshend's short essay that is printed on the album sleeve, the specially commissioned photographs that are used to convey a sense of period, in the lyrics, and the soundscapes located in the gaps between the conventional tracks. Townshend's rough and final draft of the essay firmly locates Jimmy in a domestic and public working-class milieu. He lives on a diet of 'chops, chips and fish fingers' and spends Saturday watching Brentford football Club, who in 1963/4 season finished sixteenth in the third division of the English Football League. Jimmy's father would be drunk every night, refuelling on the 'quintessentially cockney' pie and mash shop and his mother had a penchant for bottles of Guinness. ${ }^{46}$ Townshend had explored similar themes in a much more superficial way on the Who single 'Dogs' (1968). Lyrically this song highlighted Townshend's awareness of the resilience of a pre-war working-class culture. There are references to greyhound racing, gambling, heavy drinking, and the consumption of pies. There is a clear nod here to Hoggart's working-class community and the way in which class cultures and identities underpinned the everyday life of work, leisure, and relationships. Similarly, one of the photographs in the Quadrophenia photo-essay contains its own image of a Hoggartian coffee bar adorned with pinball machines, Americana, and Pepsi-Colas. Yet it remains quintessentially British with its basic bare furnishings and lacking the colour and vibrancy of an American diner. ${ }^{47}$

Quadrophenia charts Jimmy's experiences in the home, workplace, club and coffee-bar, but it is also a comment on the experiences and problems that youth faced more generally in the post-war Britain of the mid-1960s and the period 1972/4. Jimmy's father is a 'socialist' and 'war veteran' who espoused the pragmatism of Attlee's post-war policies that by the 1960s were being challenged by a new generation of activists in the party and the wider trade union movement who were critical of the limitations of established labour leaders. ${ }^{48}$ Leaving school at fifteen, Jimmy is later employed by the local authority as a dustman and like Arthur Seaton 
in Saturday Night and Sunday Morning (1958) sees work as a means to an end in fuelling his hedonism. His attitude exposed the declining deference that was a feature of the trade union movement and labour politics more generally in the 1960s. In the essay, Townshend notes that Jimmy felt that the workers saw the local council as 'a sort of church', and 'the mayor as the Pope'. ${ }^{49}$ This was a characterisation of pragmatic Morrisonian socialism that had delivered much to the post-war working-class. ${ }^{50}$ Yet to Jimmy's generation this had almost anaesthetised the working-class of the 1960s to the point in which 'they sit and stew while whole the world gets worse and worse'. ${ }^{51}$ The conflict between the socialism of Jimmy's father and the youths of the 1960s is further expressed in the track 'Is It Me' that was not included on the original release, but later appeared on Townshend's director's cut in $2011 .{ }^{52}$ Here we are introduced to a conversation between two fathers as they extol the virtues of the British working-class, and the decency and dignity gained from Attlee's post-war socialism of public ownership and the creation of the welfare state. The patriarchs are perplexed by the fact that their 'chosen path' had led to such a generational fracture in working-class families. The father of 'Ace' (Bell Boy) another central character in Quadrophenia was a friend of Jimmy's father and they 'were old-school working-class socialists' both disdainful of the fact that their mod sons were immune to the solidarities and communalities of pragmatic post-war British socialism. ${ }^{53}$

Quadrophenia's Jimmy sees only conservatism and conformity in his parents' generation, but he also feels the pull and push of the London working-class from which he emerged. Through self-reflection he questions his own critique of his father's 'chosen path' which is articulated in 'Is It In My Head' (track 9). This process was also noted by Hoggart in his characterisation of the 'grammar school' boy in The Uses of Literacy (1957). Yet unlike Hoggart's youths, Townshend's Jimmy is not the 'depressing' 'juke-box boy' and 'passive consumer' of popular music. He represents a section of working-class youth who in the mid-1960s were using song, sound, and lyrics as a source of expression to make sense of their lives and their role in wider British society. The promise and futility of this is most clearly expressed in Quadrophenia's, 'The Punk and the Godfather' (track five). A key-event in the 3-day chronology of the album's narrative is Jimmy's sense of betrayal at the distance created between Townshend, the Who and the mod fan base that they had attracted. Townshend's 'Godfather' is one of many characters created in the 1960s and early-1970s symbolising the messianic potential of the rock star; see also Steven Shorter in Peter Watkins' film Privilege (1967), Johnny Angelo in Nik Cohn's novel I Am Still The Greatest Says Johnny Angelo (1967) and Ziggy Stardust in David Bowie's album The Rise and Fall of Ziggy Stardust and the Spiders from Mars (1972). ${ }^{54}$ The potency of rock music and its contribution to new forms of politics and struggles is also explored in Tony Palmer's documentary All My Loving (1968). ${ }^{55}$ In all of these examples there is a clear sense that popular music and the rock star are offering something new to working-class youth that might to some seem to be ambiguous, shallow, corrupting, ultimately futile, but is nonetheless potent and transformative. The promise and betrayal of popular music that is encapsulated in 'The Punk and the Godfather' is also a reflection on the limitations of the counter-culture that Townshend had first explored in 'Won't Get Fooled Again' (1971) as part of the aborted Lifehouse project. ${ }^{56}$

Jimmy's engagement with the mod subculture is conditioned by his inability to truly belong. In 'Cut My Hair' (track 4) he is critical of the perceived unwritten rules and codes of the mod subculture and acknowledges that his father is 'really alright'. The track spans the domestic sphere and the more open/public terrain of fashion, violence, and public transport. The historical focus of the album on 1964/5 reveals much about the period and the contuities and ruptures in the working-class world of work, home, and street. A similarly un-swinging 1960s is also uncovered in Geoffrey Moorhouse's The Other England (1964). ${ }^{57}$ The domestic 
images in Quadrophenia's accompanying photographic essay bear similarities to Ken Loach's drama Cathy Come Home (1966) and the 'kitchen-sink politics' of the working-class home. ${ }^{58}$ Domestic roles are clearly defined and Jimmy's interventions both reinforce and subvert the functioning of the nuclear family. Such reinforcement comes from Jimmy's embrace and promotion of gender identities and contemporary conceptions of masculinity and femininity. His bedroom is plastered with the low-grade and gritty pornography indicative of the English 1960s as opposed to the high end eroticism and 'swinging imagery' of the period's mythology. A scene similar to the one Townshend had earlier evoked on the hit single 'Pictures of Lily' (1967). Yet Jimmy's apparent alienation from the post-war norms and attitudes of the working-class also forms a critique of such culture. The images in Quadrophenia and the attitudes evoked contrast with the mythologies of 'swinging London' narratives and images of the Wilson Government's new society built on the 'white heat of technology'. Wilson was elected in October 1964 after the seaside clashes of the mods and rockers that had taken place between March and August. His rhetoric and the liberalising reforms of his administrations between 1964/6 and 1966/70 have been used by some historians to highlight the ruptures in society and the creation of a 'new Britain'. ${ }^{59}$ Yet contemporary observers such as Townshend and Ray Davies of the Kinks were already critiquing the claims being made for the changing lives of the working-class in this period. The workers featured in Quadrophenia are clearly an industrial and traditional working-class and their teenage children are grappling with the legacy, meaning, and tensions of such experience and identity in the domestic and public sphere. Jimmy's frustrations and keenly felt in 'I'm One' (track 6) and the repetitive nature of a working-class world underpinned by the rigidity of work and the monotony of physical labour. The temporary release provided by the being a mod remains ultimately unfulfilling in the search for identity. Similar experiences are depicted in Sidney J. Furie's film of the pulp novel The Leather Boys (1964). ${ }^{60}$ As in Quadrophenia, working-class youths soon become aware of the limitations of youth culture in being able to transcend social status, conventions, and economic inequalities.

The themes, images, sounds and experiences that are contained in Quadrophenia highlight the continuities in working-class class culture in the post-war period. Sea, sand, sex, hedonism, deference, and rebellion all feature in the lyrical content, sonic components, and accompanying text and photographs. Rain, water, waves, and sand complement the key themes/personalities/soundscapes of the opening track 'I Am The Sea' (track 1). The sea remains a source of escape and reflection, the sand represents the collective memory of annual holidays and collective forms of leisure. The seaside is a space for the hedonism of drink, dance and sex. The rebellion is illustrated by the rampaging mods and rockers. In contrast to Ray Davies' nostalgic colourful presentation of Blackpool in 'Autumn Almanac' (1967) Townshend's and Jimmy's Brighton is both a scene of transgression and liberation, but also one of conservatism, conformity and class rigidities. ${ }^{61}$ It is also an image of a darker Britain beyond the bright lights and candy floss. The photos depict a weather beaten resort of empty beaches, brown seas, windswept promenades, down at heel cafes and creaking piers.

Brighton dominates two sides of the album and is featured most prominently in 'Sea and Sand' (track 12), 'Drowned' (track 13) and 'Bell Boy' (track 14). The seaside here being a both a traditional working-class one of collective hedonism, but also in Jimmy's case providing a geography of expulsion, self-discovery and ultimate failure. The personal journey here moves from his eviction from the family home to bright lights and pulsating music of the 'ballroom' through to the self-doubt and painful discovery that the mod subculture cannot provide any answers to his inner longings and confusions. In 'Drowned' (track 13), Jimmy places hope and the possibility of release/escape in the tides of the ocean; this being a reflection of the working-class culture and childhood memories of Brighton, Margate, 
Southend, and Clacton. Contemporaries of Townshend, including John Lennon, Georgie Fame, and Van Morrison also recalled the importance of the British resorts such as Blackpool, Douglas, and Bangor as having similarly mythical qualities. ${ }^{62}$ In 'Bell Boy', Jimmy is exposed to both the liberating aspects of Brighton and its place as the site of the betrayal of the mod subculture. Jimmy's return to Brighton depicts a faded resort beyond the bright lights, hedonism and escape of the seaside. The greasy spoon café, deserted pier and grey/black sky, providing an image more attuned to the reality of the working-class holiday than to the colour, warmth, and levity of the mythical British postcard. ${ }^{63}$

The death of Winston Churchill in January 1965 and the election of Ted Heath as Conservative Party leader in the following July might have signalled a new politics, but the re-election of Wilson in 1966 and the subsequent fall of Labour in 1970 again exposed the rigidity of the class system and the limitations of British socialism. Quadrophenia captures the complexity and personal experience of this process. After 1966 the mods might have grown up, fragmented or moved into other examples of subcultural activity such as skinhead and northern soul, but music and fashion remained a source of identity, escape, and protest. The writing, recording, and release of Quadrophenia in 1972/3 provides a further insight into a Britain that was beset by economic problems, political extremism, nationalist tensions and the cultural politics of class.

\section{Crisis, conflict, and the post-war consensus 1972/3}

Quadrophenia was written and recorded in the 'two stormy summers' between 1972 and 1973 . $^{64}$ The soundscapes between the seventeen tracks on the album are markers of a collective working-class experience of work, home, and leisure that was both contemporary and historical. Some of the tracks reflected the economic, cultural and social contexts of British life in the early 1970s. In 1973, the recording sessions for Quadrophenia could have been hampered by the energy shortages that occurred as a result of the miners' overtime ban and the Who's Ramport Studios in Battersea were supplied with generators to minimise any disruption. ${ }^{65}$ The recording of the album had already been completed before the 3-day week to conserve energy came into effect in 1974. Nonetheless, the blackouts of 1972 engendered by the first national miners' strike since 1926 and the announcement by the Conservative Prime Minister Ted Heath that the country was now in 'a state of emergency' did much to instil a sense of 'crisis'. In the same year, unemployment had risen to the highest levels since the depression of the 1930s. ${ }^{66}$ The everyday life of the working-class in this period was punctuated by rising food prices, fuel shortages, and violence on the streets in the shape of Provisional Irish Republican Army (IRA) bombs and agitation by the extreme right and left in the form of the National Front and the International Socialists. Youth culture was inhabited by a number of subcultures, tribes and styles including; glam rockers, teddy boys, skinheads, suedeheads, hell's angels, and the northern soul scene. ${ }^{67}$ Unlike the counter-culture of the late-1960s all of these identities/movements were firmly rooted in working-class communities. $^{68}$

Townshend's mods in general and Jimmy in particular are not the sophisticated, metropolitan mould-breakers of MacInnes' Absolute Beginners (1959) or the 'dandies of the 1960s. The Jimmy of Quadrophenia is a young working-class 'dustman' who is disdainful of the way in which older trade unionists have been moderated by a particular form of Labour socialism that promised so much in the 1960s. The trails, tribulations, and political dislocation of Jimmy are of relevance to both 1964/5 and 1972/3. Generational conflict in the workplace and in the trade union movement had been highlighted by the Donovan Commission in 1968 which had noted declining deference between leaders and members and the growing power of 
shop stewards on the shop-floor. ${ }^{69}$ The Labour Government's attempt to tackle particular industrial relations problems in 1969's 'In Place of Strife' proposals created divisions in the labour movement and ended in failure. The election of the Conservatives under Ted Heath in 1970 symbolised a right-ward shift in the party, but his attempts to enforce the principles of his industrial relations policies in 1971 led to a mass campaign by the trade union movement which effectively rendered the legislation powerless and it was repealed in $1974 .^{70}$

There is no doubt that when writing Quadrophenia, Townshend was writing about the past, but with one eye on the contemporary events of 1972/3. The mods' relationship with aspects of working-class politics, identity and experiences is explored most directly in 'The Dirty Jobs' (track 7), where Jimmy confronts his fellow workers by critiquing their industrial and political moderation. The song was recorded in the summer of 1972 during a year of a national miners' strike that had seen the effective use of mass picketing and a younger more militant strand of trade unionist challenging the diktats of their moderate leaders. ${ }^{71}$ Sonically, the song was also able to 'evoke the sense of men at painful work, being used like machines rather than human beings with feelings' ${ }^{72}$ The track also contains sound samples/effects that sound like they are from a trade union demonstration and or picket line chanting. ${ }^{73}$ Recorded in July 1972 it echoes working-class militancy and strike action that reached its most dramatic stage in the miners' dispute that lasted from 9 January to 28 February of that year. The moderate president of the National Union of Mineworkers (NUM), Joe Gormley, was unable curtail the mood of his members who had been suffering from falling wages, rising prices and colliery closures in the previous six years. ${ }^{74}$

Jimmy's short exposure to the political moderation of his co-workers leads him to question their masculinity and to 'remember how they used to fight'. The title of the track is a direct reference to the 'dirty jobs' dispute that erupted in October 1970 and led to the 'dust men' going on strike amid scenes of uncollected rubbish and the increase of pollution in London. ${ }^{75}$ Gormley himself was critical of the way in which 'dust men' were now overtaking miners in terms of income levels. He told the NUM conference in 1971 that he was 'not going to be a miners' leader if I cannot claim a bigger minimum wage for the lads who go underground than the lads carting the dustbins around London' ${ }^{76}$ Townshend references the coal industry and the 1972 miners' strike in the lyrics of 'The Dirty Jobs' (track 7) which also features a bus driver (in some live presentations the driver appears as Jimmy's uncle) who transports the 'miners to pits' that were presumably closed because of strike action. Interestingly, in 1972 the closest coal mines to London were Betteshanger, Snowdown, and Tilmanstone located in the Kent coalfield around 80 miles away but ones which were steeped in trade union militancy. ${ }^{77}$ Yet such was the country's dependence on coal that no locality was immune to impact of disputes in the industry. The National Coal Board (NCB) remained a huge concern in 1972 employing over 260,000 and the NUM membership standing at well over 200,000 miners. ${ }^{78}$ The closure of the Saltley fuel depot in Birmingham in February 1972 marked a symbolic victory for the miners and organised labour. In the period in which Quadrophenia was written, recorded and released the coal industry was regularly headline news. The picket line chanting that precedes 'Helpless Dancer' (track 8) reflecting the activism, collective voice, and power of organised labour.

In 'Helpless Dancer' (track 8), Townshend exposes the inequality, racism and poverty that remained a feature of British society in 1972/3. He later claimed 'the song is about the last vestiges of a real Red Flag inspired workers' revolution through flash miners' strikes in the United Kingdom in 1972 that were sparked by mining disasters and poor working conditions from 1963 all the way to the recording'. ${ }^{79}$ Townshend had no doubt heard reports in March and July 1973 of the disasters at Lofthouse Colliery in Yorkshire and Markham in Derbyshire 
which left 25 miners dead and many others injured. The sample of a brass band that precedes the track is also evocative of a pre-war Hoggartian working-class culture that was fragmenting, but still remained a crucial feature of coalfield communities. ${ }^{80}$ Townshend also understood the ideological battles that were being fought in the British labour movement and the 'mood of disgruntled British workers in unions being forced to consider Marxism over socialism'. ${ }^{81}$ Jimmy himself expresses 'rage at both the oppressed worker's impotence and those who oppressed them, ${ }^{82}$ Similar ground is covered by Ray Davies in the ambiguous critique of trade union leadership 'Get Back In Line' (1970). ${ }^{83}$ The power of organised labour ultimately found its apotheosis in the Strawbs hit single 'Part of the Union' (1973) released in the same year as Quadrophenia.

Townshend's awareness of the limitations of the counter-culture of the 1960s and the continuing extent of inequality that is articulated in 'Helpless Dancer' (track 8) was also being given more serious and analytical treatment in social investigations such as Ken Coates and Alan Silburn's, Poverty: the Forgotten Englishmen (1970). ${ }^{84}$ The track also references violent attacks on homosexuals and ethnic minorities that were a significant feature of urban and rural localities in 1972/3. ${ }^{85}$ On 1 July 1972 the first Gay Pride march had traversed the familiar route of mass protest from Trafalgar Square to Hyde Park. ${ }^{86}$ A year later studies exposed the level of endemic racism in the police force. ${ }^{87}$ Again, in 'Helpless Dancer' (track 7), Britain is a country that remains desperately divided by class and ethnicity. Here again we see Townshend's and Jimmy's frustration with the limitations of the post-war consensus. The track also contains a darkness that conveys the city as a place of immorality and urban danger where 'if you complain you disappear'. ${ }^{88}$ In the early 1970s the metropolis was being investigated by reporters and concerned politicians who aimed to expose its endemic social problems. For runaway teenagers the bright lights of the city invited opportunity and transgression, but also a reality of poverty, violence and sexual abuse. ${ }^{89}$ To Blackwell and Seabrook, 'the better world that that had been constructed on the ruins of the Victorian manufacturing towns was already beginning to show signs of disrepair. Not only had the factory-constructed blocks begun to leak and subside and graffiti and litter disfigure the landscaped surroundings, but also many of the structures of common life itself seemed to be breaking under the strain'. ${ }^{90}$

A further microcosm the British class structure and struggle is encapsulated in the photograph in the album that is placed to underpin the narrative that complements Jimmy's return to Brighton on ' 5.15 ' (track 11). Unlike the Kinks 'Last of the Steam Powered Trains' (1968) which is an elegiac and nostalgic lament for a lost Britain and individual identity, Townshend's train remains a site of social contempt and class struggle. ${ }^{91}$ In the 'first class' compartment of the London to Brighton train, Jimmy attempts to subvert the generational and class divide of post-war Britain. Seated 'magically bored' between the bowler hatted city gents his demeanour and deportment suggesting a sneering, but ultimately futile critique of the class structure that Labour's post-war socialism had failed to dismantle. The heavily unionised British Rail was both a conduit for industrial militancy, but also a symbol of the pragmatism of the post-war consensus. The 'Beeching cuts' that led to the closure of branch lines and stations (peaking in 1964) and the replacement of steam by diesel failed to diminish the role of the railways in British national identity and in the collective psyche of the postwar working-class. By 1972/3, trains were transporting armies of young people to football matches where terrace violence was becoming endemic, and to the traditional seaside resorts for drink, music, sex, and summer violence. ${ }^{92}$

The characters depicted in Quadrophenia's photo essay were also mostly drawn from the working-class youth who lived in the Thessaly Road area of Battersea and the Patmore 
council estate. A formal politics remains absent from the images, but when viewed in conjunction with listening to the sonic narrative the everyday life of Battersea's workingclass becomes apparent. The shot of the terraced housing, Queenstown Road with Battersea Power Station in the background, the greasy breakfast, and the piles of rubbish, create a scene largely untouched by the affluence and consumerism of the 1960s. Politically, Battersea remained solidly Labour from 1964-79 in voting patterns and in the broader cultural pursuits of the working-class. The constituency had been represented by the socialist pioneer John Burns from 1892-1918. In 1922 Battersea North had been won by the Communist Sharpurji Saklatvala. From 1964-79 the two seats (Battersea North and South) were held by Ernie Parry and Douglas Jay. The neighbouring Vauxhall seat was also strongly Labour and was represented by George Strauss. ${ }^{93}$ The mods of the 1960s in this area and the then contemporary youth of 1972/3 of Battersea were not the upwardly mobile affluent consumers of 1960s mythology, but industrial workers steeped in traditional working-class culture that was yet to be swept away by the forces of deindustrialisation and the later politics of Thatcherism.

The spiritual dimension of the work and Jimmy's quest for some kind of enlightenment also reflects the then contemporary working-class interest in the esoteric, the supernatural and the fantastic. Jimmy's Catholic background no doubt shaped his quest for some kind of religious confirmation. The legendary record producer Joe Meek and Dave Davies of the Kinks also made incursions into alternative forms of knowledge and belief systems in the 1960s. ${ }^{94} \mathrm{John}$ Entwistle, the Who's bassist, was a practising freemason with a fascination with the macabre. Keith Moon, the drummer, was an avid viewer of British horror films. Townshend himself had become a devotee of the Indian spiritual master Meher Baba. ${ }^{95}$ In 'Drowned' (track 13) his characterisation of Jimmy's engagement with the sea is a quest for enlightenment. The 1970s ushered in a 'golden age' of supernatural television and film and what were perceived to be the 'real' hauntings of the working-class domesticity. This culture reached its most sensational peak in 1977 with the Enfield poltergeist case, one of many working-class ghosts of the 1970s. ${ }^{96}$ With its thunder, rain, and crashing waves Quadrophenia evoked a similar darkness. The last five pictures of the photo essay depict a dark, gothic image of the sea, sand and doom laden sky. The economic and cultural crisis of the years 1972-1979 no doubt added to the sense of foreboding that gained popular currency in the media and the rhetoric of politicians of both left and right. Yet it was also indicative of the continuities in aspects of working-class culture that had been immune to affluence and new forms of consumerism and technology.

In cultural terms, Quadrophenia was again both a historical perspective on the 1960s, but also a contemporary critique of British society in 1972/3. It shared particular themes and tropes with two key-films that were released in the same year: Claude Whatham's, That'll Be The Day (1973), and Lindsay Anderson's, O Lucky Man (1973); and to a lesser extent Stanley Kubrick's A Clockwork Orange (1971) that was on general release a year later. ${ }^{97}$ These films bear similarities to Quadrophenia in terms of period, subject matter, and offer particular versions of the numerous 'state of the nation' polemics and interventions that were a feature of the decade. Whatham's That'll Be The Day (1973) based on a screenplay by the journalist Ray Connolly explores the impact of American rock ' $n$ ' roll on British society and is very loosely based on the career trajectories of the seminal working-class British pop/rock stars of the $1950 \mathrm{~s} / 60 .{ }^{98}$ Its release also chimed with a Teddy Boy revival that was symbolised by the 'Rock 'n' Roll Festival' at London's Wembley Stadium in August 1972. Anderson's $O$ Lucky Man! (1973) follows the trials and tribulations of Mick Travis through a country beset by local government corruption, rigid class hierarchies, and decaying urban environments. 
And finally, Alex in A Clockwork Orange (1971) is the anti-hero of a dystopian society beset by juvenile delinquency and gang violence. ${ }^{99}$

Given the contemporary context, Jimmy was a much a character of 1972/3 as he was of 1964/5. The violent of aspect of youth culture was also exploited in 1970-74 through cult novels by Richard Allen, particularly Skinhead (1970), Skinhead Escapes (1972) and Trouble for Skinhead (1973). ${ }^{100}$ The visual style of the album artwork also shares similarities with the cinematic depiction of 'suedeheads' in Barney Platts Mills Bronco Bullfrog (1969), which also features a more nuanced and darker vision of late-1960s London. ${ }^{101}$ In the months following the release of Quadrophenia, the vermin carrying the dreams of children referenced in 'Helpless Dancer' (track 8) rampage through London's urban landscape in James Herbert's hugely successful horror novel The Rats (1974). ${ }^{102}$ The filth, greyness, and detritus of London's streets had been amply depicted on pages 9, 10, and 11 of the album's photo essay. Four year later, the screen version of Quadrophenia was developed and directed in a further period of economic crisis and litter strewn streets, leading to impending political transformation.

\section{Quadrophenia redux, Thatcherism, and the 'fragmentation' of Britain 1978/9}

The salience and longevity of Quadrophenia was confirmed by the cinematic treatment that the album received at the end of the decade. The film was directed in 1978/9 by Franc Roddam who himself had aimed to explore the character of Jimmy in a broader social and cultural context of post-war Britain. ${ }^{103} \mathrm{He}$ came to the film with little knowledge of the album, but an acute awareness of the importance that popular music had played in the construction of teenage working-class identities in the 1960s. Influenced by the generation of film and documentary makers of the British 'new-wave' he was less concerned with the 'spiritual aspects' of the narrative and more interested in making a youth film that was rooted in the realities and lives experiences of the 1960s and 1970s. ${ }^{104}$ Yet the attempt to 'centre' class in the overall scope and feel of the film is only partly successful. The politics of the 'everyday lives' of the working-class that are a solid feature of the films of British directors such as Ken Loach and to a lesser extent Mike Leigh are marginalised in favour of documenting familiar and mythologised aspects of the popular culture of the 1960s. Roddam aimed to capture the detail of the period and the visible impact that social changes were having on urban working-class youth and in this respect the film is largely convincing. The film complements the album in a number of ways, but ultimately the cultural and industrial politics of class that featured on the album is largely absent. ${ }^{105}$

The film has been the subject of some excellent critical analysis and it has found a place in the pantheon of British cult classics. ${ }^{106}$ Yet most scholars and critics have often failed to examine the differences between the album and its cinematic treatment and the ways in which the making of the film corresponded with the final assault on the post-war consensus, industrial conflict, and the advent of the politics of Thatcherism. Roddam's attempt at social realism in his endeavours to capture the 'reality' of the mod culture of 1964/5 was mostly successful, but the film is lighter in colour and tone than the original album narrative and accompanying photo-essay. The fist photograph in the album's photo essay featuring the grey terraced housing of Battersea (a scene that owes much to stock images of the streets of the northern working-class that appeared on television and film in the 1960s and 1970s) is replaced by Jimmy riding his scooter down a vibrant road containing the pulsating features of the affluent British high street. In many ways, the film signposts aspects of youth culture and the dilution of working-class identity in its individual and collective form that would become a feature of Britain in the 1980s. 
Production started in the summer of 1978 with filming beginning in September and general release in August 1979. As with the 'two stormy summers' of the making of the original album, the shooting of the film coincided with seismic shifts in Britain's economy, politics and popular culture. The economic instability that had rocked the country in 1976-77 had been momentarily tempered by Jim Callaghan's Labour Government. The trade unions had been placated by the 'social contract', but by 1978 the fragile unity between the party and the movement began to fragment. In the month that Quadrophenia began filming, Callaghan refused to call an expected general election. The events that followed would transform British politics and the Labour Party would remain out of power until 1997. The 'Winter of Discontent' which centred on low-paid workers in the public sector in 1978-9 once again exposed the fault lines in British society that remained divided by class, ethnicity, and region. ${ }^{107}$ The dramas of 'The Dirty Jobs' (track 7) and 'Helpless Dancer' (track 8) were played out over kitchen tables, clubs, pubs, bingo halls and party committee rooms. Miners continued to die in the mines evidenced by the Golbourne explosion in 1978, and trade union solidarity was expressed in the mass pickets of the Grunwick dispute of 1976-8. Yet this period was to witness the defeat of the organised working-class in a most systematic way through electoral politics, government legislation, and the forces of the British State. The minorities of 'Helpless Dancer' (track 8) continued to face daily racism and exploitation. Attempts to fight back such as in Southall in 1979, led to violence and the death of Blair Peach, and campaigns against persecution by an institutionally racist Metropolitan Police, were exposing significant fault lines in British society. ${ }^{108}$

The election of Margaret Thatcher in May 1979 and subsequent victory of the Conservatives in 1983 reversed many of the advances that the organised working-class had made in the years 1964-74. The labour institutions that had shaped the political and cultural conscious of Jimmy's father, and to a lesser extent Jimmy himself were systematically dismantled through significant pieces of legislation that eroded the rights of employees in the workplace. The failure of the strike in the steel industry in 1980 was followed by the calamitous defeat of the coal miners in 1984/5, and the printers a year later. ${ }^{109}$ The 'chosen path' of Jimmy's father's generation was destroyed by deindustrialisation, privatisation, and the economics of globalisation and neoliberalism. The working-class of Shepherd's Bush and Battersea largely continued to vote for the Labour Party, but the broader zeitgeist suggested that the Labour socialism that had been constructed by Attlee in the post-war period was in retreat. This aspect of Quadrophenia continued to inform the Who's vision of the piece in the subsequent concert tour of 2012-13 with accompanying film presenting a montage of the post-war consensus that included the Welfare State, the National Health Service (NHS) and the NCB. ${ }^{110}$

The filming of Quadrophenia was bookended by two waves of youth subculture that once again gave rise to vibrancy, violence, and a working-class incursion into the music industry and the politics of the street. Some of the mods and skinheads who had been contemporaries of the album had found a home in the pulsating working-class Northern Soul scene of the industrial English Midlands, Lancashire/Yorkshire and north Wales. Elements of the original rhythm and blues and soul sounds that the mods had absorbed in 1964-5 were now being devoured in draughty provincial halls and the faded grandeur of the Wigan Casino. ${ }^{111}$ From late-1976 to 1978 punk rock had made records, anti-heroes and headlines. The energy and experiences of punk are clearly there in the origins, personnel and filming of Quadrophenia, but the politics is largely absent. ${ }^{112}$ When the film was completed a full-scale mod revival that had germinated prior to the film's initial production schedule in 1978, but by the time of its release a year later it was a national phenomenon. ${ }^{113}$ Roddam's film was strengthened by 
the contributions of original mods and Who fans such as Pete Meaden, Alan Fletcher and Jack Lyons. ${ }^{114}$

The film treatment lacks the gritty realism of the album and in many ways articulates many of the stock mythologies of the 1960s. The fact that it was shot in colour is a significant departure from the feel and tone of the album. On one level it depicts the 'swinging London' of MacInnes's Soho rather than the coffee bars and juke box boys of Hoggart's workingclass. Jimmy in this version is not a 'dust-man' but a runner for an adverting agency. His father on screen is constructed here as rather 'one dimensional' as opposed to the veteran socialist and trade unionist that Townshend had in the mind for the original concept. The dirt, grime and monotony of everdaylife and the working-class politics of 'The Dirty Jobs' (track 7) and 'Helpless Dancer' (track 8) is also notably absent. Both tracks are also omitted from the accompanying soundtrack album. ${ }^{115}$ Some of the original tracks from the 1973 album are also given polish through orchestration. The inclusion of an assortment of rhythm and blues tracks from the 1960s also gives the soundtrack an overt sense of nostalgia and plasticity.

The individualism and autonomy of the mods on screen is perhaps a pointer to the politics of the 1980s where solidarity, communality, and the remnants of a working-class culture that had been preserved by the post-war consensus would be almost destroyed through deindustrialisation, a rapid collapse in the number of trade unionists, and the neutralisation of the political left. However, the reception, consumption, and use of the film and the soundtrack suggest a greater complexity. The mod revival which accompanied the production and release of the film was predominantly working-class. ${ }^{116}$ Once again thousands of teenagers were defining themselves through a subcultural identity and activity that formed one response to the economic and social context of 1978-80. Mods appeared in schools, youth clubs, factories, coal mines and the service sector of the economy. Violence was reported at seaside resorts and the incoming Conservative government constructed sections of working-class youth as a contemporary social problem. The success of the film and subsequent live tours, theatrical productions, and even an academic conference gave Townshend's Quadrophenia greater salience in the twenty-first century. ${ }^{117}$ The music of the Who and the place of the mods remain symbolic as markers of the explosion and impact of popular culture on working-class youth in post-war Britain.

In conclusion, the work of Pete Townshend in general and Quadrophenia in particular has been overlooked by historians when charting the ways in which popular music was providing a critical commentary on the continuities and changes that were a feature of British workingclass life in the 1960 and 1970s. Quadrophenia presents a more nuanced and sophisticated analysis of mod and 'swinging London' than exists in some of the more popular and academic narratives of the period. The album is a compelling slice of social history that should be 'read' alongside the sociological and historical explorations of youth in post-war Britain. Moreover, it offers an insight into the world of London's working-class in Shepherd's Bush and Battersea in 1964/5 and 1973/4 that would never quite be the same again after the impact of Thatcherism, de-industrialisation, and the neutralisation of particular forms of labour politics. The promise of the post-war consensus in these years had its limitations, but offered much to Jimmy's generation in terms of affluence, economic democracy, and equality. Yet, this proved to be brittle. From the vantage of the twenty-first century we can now see that 'things ain't quite that simple'. 


\section{Notes}

${ }^{1}$ The album was recorded and released under the name of The Who but the concept, lyrics, and music were credited to Townshend. In the sleeve notes to the album the credits list "Quadrophenia" in its entirety by Pete Townshend. The Who, Quadrophenia (Track Records, 1973) LP.

${ }^{2}$ For details of strikes in this period see Dave Lyddon, 'Glorious Summer, 1972', in John McIlroy, Nina Fishman and Alan Campbell (eds), The High Tide of British Trade Unionism: Trade Unions and Industrial Politics, 1964-79 (Monmouth, 2007), pp. 326-352.

${ }^{3}$ Roger Daltrey of the Who also made a significant contribution to anchoring the narrative of Quadrophenia in the broader context of post-war politics, deindustrialisation and the plight of the British working-class in later incarnations of the piece for live performances in 1996/7 and 2012/13. For details see audio commentary on The Who, Tommy and Quadrophenia Live (Rhino, 2005) DVD.

${ }^{4}$ Quadrophenia in particular and Townshend's work more generally has been neglected by historians of the post-war period. The album does not merit a reference in three highly regarded books on the history of 1970s: Dominic Sandbrook, State of Emergency: The Way We Were, 1970-1974 (London, 2010); Andy Beckett, When the Lights Went Out: Britain in the Seventies (London, 2009); and Alwyn W. Turner, Crisis? What Crisis? Britain in the 1970s (London, 2008).

${ }^{5}$ For a similar use of popular music as a significant historical source see Keith Gildart, Images of England: Class, Youth and Rick ' $n$ ' Roll, 1955-1976 (Basingstoke, 2013).

${ }^{6}$ Alan Sillitoe, Saturday Night and Sunday Morning (London, 1958).

${ }^{7}$ Karel Reisz, We Are The Lambeth Boys (1959) (Duke Video, 2009) DVD.

${ }^{8}$ Michael Young and Peter Willmott, Family and Kinship in East London (Harmondsworth, 1957).

${ }^{9}$ Anthony Sampson, The Anatomy of Britain (London, 1962).

${ }^{10}$ Nell Dunn, Up The Junction (London, 1963) and Poor Cow (London, 1967).

${ }^{11}$ Pete Townshend, Quadrophenia: The Director's Cut (UMC, 2011) CD.

${ }^{12}$ Colin MacInnes, Absolute Beginners (London, 1959). The link between mod, affluence, and the 'new' working-class of post war-Britain is also reiterated in the two significant critical studies of the film: Stephen Glynn, Quadrophenia (London, 2014) and Simon Wells, Inside The Making of Britain's Greatest Youth Film: Quadrophenia A Way of Life (London, 2014).

${ }^{13}$ For the Kinks and the working-class see Keith Gildart, 'From Dead End Streets to Shangri Las: Negotiating Social Class and Post-War Politics with Ray Davies and the Kinks', Contemporary British History, 26, 3 (2012) 273-98.

${ }^{14}$ Some of the material in this section also appears in Gildart, Images of England, chapter 4.

${ }^{15}$ For autobiographical/biographical details see Pete Townshend, Who I Am (London, 2012); Geoffrey Gialiano, Behind Blue Eyes. A Life of Pete Townshend (London, 1996) and Mark Wilkerson, Who Are You. The Life of Pete Townshend. A Biography (London, 2009). There is also some useful information in the early chapters of Dave Marsh, Before I Get Old: The Story of the Who (London, 1985).

${ }^{16}$ Pete Doggett, There's A Riot Going On: Revolutionaries, Rock Stars and the rise and fall of the 60s Counter Culture (Edinburgh, 2007).

17 Townshend, Who I Am, p. 4.

${ }^{18}$ New Musical Express, 12 March 1983.

${ }^{19}$ Along with John Lennon, Ray Davies and John Lydon, Townshend was arguably one of the four most significant 'organic intellectuals' in the post-war popular music industry who through their work explored and critiqued aspects of British society. For further discussion of musicians as 'organic intellectuals see Gildart, Images of England, introduction.

${ }^{20}$ Pete Townshend, 'Two Stormy Summers', in Quadrophenia: The Director's Cut, p. 16.

${ }^{21}$ In the 1930s Townshend's father had briefly been a member of the British Union of Fascists. See Townshend, Who I Am, p. 8.

${ }^{22}$ Townshend, Who I Am, p. 35.

${ }^{23}$ Townshend, Who I Am, p. 33.

${ }^{24}$ For the roots of the Who and the various permutations that led to their formation see the early chapters of Marsh, Before I Get Old.

${ }^{25}$ See Townshend, Who I Am, p. 56. For the culture of art schools and their connection to the popular music scene of the 1960s see Simon Frith and Howard Horne, Art into Pop (London, 1987), chapter 3.

${ }^{26}$ Kevin Davey, English Imaginaries: Six Studies in Anglo-British Modernity (London, 1999), p. 81. Townshend does not shed light on whether he was a member of these organisations in his autobiography.

${ }^{27}$ Robin Denselow, When The Music's Over: The Story of Political Pop (London, 1989), p. 93.

${ }^{28}$ Denselow, When The Music's Over, p. 95. 
${ }^{29}$ Townshend claims that the title came from Generations a collection of plays by the socialist playwright David Mercer. Townshend, Who I Am, p. 83.

${ }^{30}$ Townshend, 'Two Stormy Summers', p. 20.

${ }^{31}$ For the place of mods in this process see P. Gilroy, There Ain't No Black in the Union Jack (London, 1987), p. 215.

${ }^{32}$ For recollections see Mark Sargeant, 'Looking back with Irish Jack', Scootering, 163, September 1999. 'Irish Jack' Lyons was one of a number of mods who Townshend drew on in creating the Jimmy character for the Quadrophenia album in 1972-3.

${ }^{33}$ Mim Scala, Diary of a Teddy Boy: A Memoir of the Long Sixties (London, 2000), p. 80.

${ }^{34}$ Joe McMichael and Jack Lyons, The Who Concert File, p. 14.

${ }^{35}$ Marsh, Before I Get Old, p. 423.

${ }^{36}$ Davey, English Imaginaries, p. 100, 102.

${ }^{37}$ Uncut, June 2009.

${ }^{38}$ The photographs were taken by Ethan Russell. For background and his work on popular music see E. Russell, Dear Mr Fantasy. Diary of A Decade: Our Time and Rock ' $n$ ' Roll (London, 1985).

${ }^{39}$ See Ritchie Unterberger, Won't Get Fooled Again: The Who from Lifehouse to Quadrophenia (London, 2011) p. 241.

${ }^{40}$ Russell, Dear Mr Fantasy, p. 210.

${ }^{41}$ Such assumptions have been largely drawn from the interviews in the seminal article on mods that appeared in Town magazine in September 1962.

${ }^{42}$ The working-class aspect of mod has often been downplayed by commentators and historians. For discussion see Richard Weight, Mod: A Very British Style (London, 2013) chapter 2.

${ }^{43}$ For inter-war working-class consumption see David Fowler, 'Teenage Consumers? Young wage-earners and leisure in Manchester, 1919-1939', in Andrew Davies and Steven Fielding (eds.), Workers' Worlds: Cultures and Communities in Manchester and Salford, 1880-1939 (Manchester, 1992), pp. 133-55.

${ }^{44}$ For a short insightful critical analysis of Quadrophenia see James Wood, 'The Kids Are Alright', The

Guardian, 30 May 2009. Another source has claimed that it was a show a year later in Brighton on 17 April 1965 that was the impetus for Quadrophenia. See McMichael and J. Lyons, The Who Concert File, p. 29. In the hand-written notes to Townshend's Quadrophenia; The Director's Cut (2011) he dates it as the summer 1964 but dedicated to the fans of 1966. Yet he has more recently reiterated that 1964 was the year. See Townshend, Who I Am, p. 245.

${ }^{45}$ Townshend, 'Two Stormy Summers', p. 15.

${ }^{46}$ Pete Townshend, draft essay included in Quadrophenia: The Director's Cut.

${ }^{47}$ The coffee bar in Quadrophenia is far less glamorous and sophisticated than those in Soho depicted by the Rank Organisation's short film on the subject in the Look at Life series made in 1959.

${ }^{48}$ For a critical appraisal of party in this period see James Hinton, Labour and Socialism: A History of the British Labour Movement 1867-1974 (London, 1983) chapter 11. For the shifting politics of the trade unions see essays in John McIlroy, Nina Fishman and Alan Campbell (eds.), The High Tide of British Trade Unionism: Trade Unions and Industrial Politics, 1964-79 (London, 2007).

49 The Who, Quadrophenia (Track, 1973) LP.

${ }^{50}$ Herbert Morrison was a Labour MP, Cabinet Minister, and London County Councillor who provided the blueprint for the party's programme of nationalisation in the post-war period. For biography see Bernard Donoghue and George Jones, Herbert Morrison - Portrait of a Politician (London, 1973).

${ }^{51}$ The Who, Quadrophenia (Track, 1973) LP.

${ }^{52}$ Pete Townshend, Quadrophenia: The Director's Cut .

53 Townshend, 'Two Stormy Summers', p. 88.

${ }^{54}$ Peter Watkins Privilege (1967) (BFI, 2011) DVD; Nik Cohn, I Am Still the Greatest Says Johnny Angelo (London, 1967); David Bowie, The Rise and Fall of Ziggy Stardust and the Spiders from Mars (RCA, 1972) LP. 55 Tony Palmer, All My Loving (1968) (Plastic Head, 2007) DVD.

${ }^{56}$ For an extended critical analysis of the Lifehouse project see Unterberger, Won't Get Fooled Again.

${ }^{57}$ Geoffrey Moorhouse, Britain in the Sixties: The Other England (Harmondsworth, 1964).

${ }^{58}$ For discussion of Cathy Come Home see John Hill, Ken Loach: The Politics of Film and Television (London, 2011) chapter 3.

${ }^{59}$ For example see Arthur Marwick, The Sixties: Cultural Revolution in Britain, France, Italy and the United States (Oxford, 1998).

${ }^{60}$ Gillian Freeman, The Leather Boys (London, 1969).

${ }^{61}$ In Blackpool on 23 September the High Numbers supported the Beatles and the Kinks at the Opera House; the only time that three of the key-groups of the 1960 s would share a stage together and influence for lyric in ' 5.15 ' referring to 'Eau-de-cologning'. 
${ }^{62}$ See Gildart, Images of England, chapter 1.

${ }^{63}$ A similar scene is created later by Morrissey in his single 'Everyday Is Like Sunday' (HMV, 1988) Single.

${ }^{64}$ For chronology and recording process see Townshend, 'Two Stormy Summers'.

${ }^{65}$ For the development of Ramport see interviews in the television documentary Quadrophenia: Can You See The Real Me? (BBC, 2012).

${ }^{66}$ For the best insightful narrative of the period see Beckett, When the Lights Went Out: Britain in the Seventies.

${ }^{67}$ For a recent reappraisal of glam rock see Simon Reynolds, Shock and Awe: Glam Rock and its Legacy

(London, 2016). See also Gildart, Images of England, chapter 7.

${ }^{68}$ This period also ushered in a 'golden age' of academic studies of youth and popular music epitomised by the Birmingham Centre for Contemporary Cultural Studies. For summary and critique see Gildart, Images of England, pp. 3-5.

${ }^{69}$ For a survey of trade union politics in this period see John McIlroy and Alan Campbell, 'The High Tide of Trade Unionism: Mapping Industrial Politics,1964-79', in McIlroy, Fishman and Campbell, The High Tide of British Trade Unionism, pp. 93-130.

${ }^{70}$ The industrial militancy of the period 1970-74 is in need of serious historical reappraisal. A brief but flawed survey can be found in Dave Lyddon, Glorious Summer: Class Struggle in Britain 1972 (London, 2001).

${ }^{71}$ A militant miner's perspective of these events can be found in Malcolm Pitt, The World on Our Backs: the Kent Miners and the 1972 Miners' Strike (London, 1979).

${ }^{72}$ Townshend, 'Tow Stormy Summers', p. 83. The track also echoes Daltrey's experiences when he was employed for five years as a sheet metal worker in a local factory.

${ }^{73}$ The author of this chapter was also responsive to the industrial elements of Quadrophenia reciting tracks from the album to get through the monotony of working 7 hour shifts underground in a North Wales coal mine.

${ }^{74}$ For an insightful account of pit closures and their impact on the politics of mining trade unionism see Vic Allen, The Militancy of British Miners (Shipley, 1981) chapter 7.

${ }^{75}$ For a contemporary account of the politics of labour in this period see Tony Benn, Office Without Power: Diaries 1968-72 (London, 1988).

${ }^{77}$ David Powell, The Power Game: The Struggle for Coal (London, 1993) p. 187.

${ }^{77}$ For the Kent coalfield in this period see Pitt, The World On Our Backs.

${ }^{78}$ For the union in this period see Andrew Taylor, The NUM and British Politics Volume 2: 1969-1995

(Aldershot, 2005) chapter 2.

${ }^{79}$ Townshend, 'Two Stormy Summers', pp. 32-34.

${ }^{80}$ The Who's bass player John Entwistle was also a fan of brass bands and the music that had emerged from the mining communities of England, Scotland, and Wales.

${ }^{81}$ Townshend, 'Two Stormy Summers', p. 85.

${ }^{82}$ Townshend, 'Two Stormy Summers', p. 85.

${ }^{83}$ For a discussion of 'Get Back In Line', see Gildart, Images of England, p. 143.

${ }^{84}$ Ken Coates and Alan Silburn, Poverty: The Forgotten Englishman (Harmondsworth, 1970).

${ }^{85}$ This period was also the high-point of corruption in the Metropolitan Police. For details see Barry Cox, John

Shirley and Martin Short, The Fall of Scotland Yard (Harmondsworth, 1977).

${ }^{86}$ For the role of gay liberation in the wider politics of the left see Lucy Robinson, Gay Men and the Left in Post-war Britain: How the Personal got Political (Manchester, 2011).

${ }^{87}$ Maureen Cain, Society and the Policeman's Role (London, 1973).

${ }^{88}$ The violence of sections of working-class youth that remained a feature of London's council estates in 1973 is explored in David Robbins and Philip Cohen, Knuckle Sandwich: Growing up in the Working-class City (Harmondsworth, 1978) part two.

${ }^{89}$ For example see Michael Deakin and John Wills, Johnny Go Home (London, 1976).

${ }^{90}$ Trevor Blackwell and Jeremy Seabrook, A World Still To Win: The Reconstruction of the Post-War Working Class (London, 1985) p. 137.

${ }^{91}$ For a discussion of the Kinks music and social class in the 1960s/70s see Gildart, Images of England, chapter 6.

${ }^{92}$ For a social history of the railways in this period see Simon Bradley, The Railways: Nation, Network and People (2015).

${ }^{93}$ For the economic and social context of the Battersea constituencies between the general elections of 1964 and 1974 see Robert J. Waller, The Almanac of British Politics (London, 1983).

${ }^{94}$ See John Repsch, The Legendary Joe Meek: The Telstar Man (London, 1989) and Dave Davies, Kink: An Autobiography (London, 1996) especially chapter 15.

${ }^{95}$ For Townshend's devotion to Baba see sections in Townshend, Who I Am.

${ }^{96}$ See Guy Lyon Playfair, This House Is Haunted: The True Story of the Enfield Poltergeist (London, 2011). 
${ }^{97}$ For a critical reading of the development of the British pop music film see Stephen Glynn, The British Pop Music Film: The Beatles and Beyond (Basingstoke, 2013).

${ }^{98}$ Ray Connolly, That'll Be The Day (Glasgow, 1973).

${ }^{99}$ For British cinema in this period see Sue Harper and Justin Smith, British Film Culture in the 1970s: The Boundaries of Pleasure (Edinburgh, 2012) particularly chapter 8.

${ }^{100}$ For a critical appraisal of Allen's novels see Bill Osgerby, 'Bovver Books of the 1970s: Subcultures, Crisis

and 'Youth-Sploitation' Novels', Contemporary British History, 26, 3 (2012) 299-331.

${ }^{101}$ For links between Quadrophenia and Bronco Bullfrog see Unterberger, Won't Get Fooled Again, p. 240.

${ }^{102}$ James Herbert, The Rats (London, 1974).

${ }^{103}$ For a detailed account of the making of the film see Wells, Quadrophenia A Way of Life.

${ }^{104}$ For a critical assessment of the 'new wave' and its impact on working-class cinema see John Hill, Sex, Class and Realism: British Cinema 1956-63 (London, 1986).

${ }^{105}$ For minutiae relating to the film see Gary Wharton, Chasing the Wind: A Quadrophenia Anthology

(Somerset, 2002).

${ }^{106}$ For example see Stephen Glynn, Quadrophenia.

${ }^{107}$ For a recent narrative of events see John Shepherd, Crisis? What Crisis? The Callaghan Government and the British Winter of Discontent (Manchester, 2013).

${ }^{108}$ For the cultural response to racism see Gilroy, There Ain't No Black in the Union Jack.

${ }^{109}$ For the most recent detailed account of the miner's strike see Francis Beckett and David Hencke, Marching to the Fault Line: The 1984 Miners' Strike and the Death of Industrial Britain (London, 2009).

${ }^{110}$ See The Who: Quadrophenia Live in London (UMC, 2014) DVD.

${ }^{111}$ For an autobiographical insight into the history of northern soul see Stuart Cosgrove, Young Soul Rebels: A Personal History of Northern Soul (London, 2016).

${ }^{112}$ The best book on the social and political context of punk remains Jon Savage, England's Dreaming: Sex Pistols and Punk Rock (London, 1991).

${ }^{113}$ For the mods of 1979 see Gary Bushell, Time For Action: The Mod Revival 1978-1981 (London, 2012).

${ }^{114}$ For a recent biography of Meaden see Pete Wilky and John Hellier, I'm the Face: Pete Meaden (London, 2016).

${ }^{115}$ A version of 'Helpless Dancer' is included on the film soundtrack, but is a truncated twenty-two second version that contains no lyrics. See Music from the soundtrack of The Who film Quadrophenia (Polydor, 1979) LP.

${ }^{116}$ See Bushell, Time For Action.

${ }^{117}$ The conference that led to the publication of this book: Here By The Sea And Sand: A Symposium on Quadrophenia, University of Sussex, 10-11 July 2014.

\section{Sources}

A Clockwork Orange, directed by Stanley Kubrick, Hawk Films, 1971

All My Loving, directed by Tony Palmer, BBC, 1968.

Allen, Richard. Skinhead. London: New English Library, 1970.

Allen, Richard. Skinhead Escapes. London: New English Library, 1972.

Allen, Richard. Trouble for Skinhead. London: New English Library, 1973.

Allen, Vic. The Militancy of British Miners. Shipley: The Moor Press, 1981.

Beckett, Andy. When the Lights Went Out: Britain in the Seventies. London: Faber and Faber, 2009.

Beckett, Francis and Hencke, David. Marching to the Fault Line: The 1984 Miners' Strike and the Death of Industrial Britain. London: Constable, 2009.

Benn, Tony. Office Without Power: Diaries 1968-72. London: Hutchinson, 1988.

Blackwell, Trevor and Seabrook, Jeremy. A World Still to Win: The Reconstruction of the Post-War Working Class. London: Faber and Faber, 1985.

Bowie, David. The Rise and Fall of Ziggy Stardust and the Spiders from Mars. RCA, 1972. Bradley, Simon. The Railways: Nation, Network and People. London: Profile Books, 2015. Bronco Bullfrog, directed by Barney Platts-Mills, EMI Films, 1969.

Bushell, Gary. Time For Action: The Mod Revival 1978-1981. London: Bertrams, 2012.

Cain, Maureen. Society and the Policeman's Role. London: Routledge 1973. 
Coates, Ken and Silburn, Alan. Poverty: The Forgotten Englishman. Harmondsworth: Penguin, 1970.

Cohn, Nik. I Am Still the Greatest Says Johnny Angelo. Harmondsworth: Penguin, 1967.

Connolly, Ray. That'll Be The Day. Glasgow: Harper Collins, 1973.

Cosgrove, Stuart. Young Soul Rebels: A Personal History of Northern Soul. London: Polygon, 2016.

Cox, Barry, Shirley, John and Short, Martin. The Fall of Scotland Yard. Harmondsworth: Penguin, 1977.

Davey, Kevin. English Imaginaries: Six Studies in Anglo-British Modernity. London: Lawrence and Wishart, 1999.

Davies, Dave. Kink: An Autobiography. London: Boxtree, 1996.

Deakin, Michael and Wills, John. Johnny Go Home. London: Futura, 1976.

Denselow, Robin. When The Music's Over: The Story of Political Pop. London: Faber and Faber, 1989.

Doggett, Pete. There's A Riot Going On: Revolutionaries, Rock Stars and the rise and fall of the 60s Counter Culture. Edinburgh: Canongate, 2007.

Donoghue, Bernard and Jones, George. Herbert Morrison - Portrait of a Politician. London: Littlehampton Book Services, 1973.

Dunn, Nell. Poor Cow. London: Macgibbon and Kee, 1967.

Dunn, Nell. Up The Junction. London: Macgibbon and Kee, 1963.

Fowler, David. 'Teenage Consumers? Young wage-earners and leisure in Manchester, 19191939'. In Workers' Worlds: Cultures and Communities in Manchester and Salford, 18801939, edited by Andrew Davies and Steven Fielding, 133-55, Manchester: Manchester University Press, 1992.

Freeman, Gillian. The Leather Boys. London: New English Library, 1969.

Frith, Simon and Horne, Howard. Art into Pop. London: Methuen, 1987.

Gialiano, Geoffrey. Behind Blue Eyes. A Life of Pete Townshend. London: Hodder and Stoughton, 1996.

Gildart, Keith. 'From Dead End Streets to Shangri Las: Negotiating Social Class and PostWar Politics with Ray Davies and the Kinks', Contemporary British History, 26, 3 (2012) 273-98.

Gildart, Keith. Images of England: Class, Youth and Rock 'n' Roll, 1955-1976. Basingstoke: Palgrave Macmillan, 2013.

Gilroy, Paul. There Ain't No Black in the Union Jack. London: Routledge, 1987.

Glynn, Stephen. Quadrophenia. London: Wallflower Press, 2014.

Glynn, Stephen. The British Pop Music Film: The Beatles and Beyond. Basingstoke: Palgrave Macmillan, 2013.

Harper, Sue and Smith, Justin. British Film Culture in the 1970s: The Boundaries of Pleasure. Edinburgh: Edinburgh University Press, 2012.

Herbert, James The Rats. London: New English Library, 1974.

Hill, John. Ken Loach: The Politics of Film and Television. London: Palgrave Macmillan, 2011.

Hill, John. Sex, Class and Realism: British Cinema 1956-63. London: British Film Institute, 1986.

Hinton, James. Labour and Socialism: A History of the British Labour Movement 1867-1974. London: Wheatsheaf Books, 1983.

Look At Life: Coffee Bars, Rank Organisation, 1959. 
Lyddon, Dave. 'Glorious Summer, 1972'. In The High Tide of British Trade Unionism:

Trade Unions and Industrial Politics, 1964-79 edited by John McIlroy, Nina Fishman and Alan Campbell, 326-352. Monmouth: Merlin Press, 2007.

Lyddon, Dave. Glorious Summer: Class Struggle in Britain 1972. London: Bookmarks, 2001.

MacInnes, Colin. Absolute Beginners. London: Macgibbon and Kee, 1959.

Marsh, Dave. Before I Get Old: The Story of the Who. London: Plexus, 1985.

Marwick, Arthur. The Sixties: Cultural Revolution in Britain, France, Italy and the United States. Oxford: Oxford University Press, 1998.

McIlroy, John and Campbell, Alan, 'The High Tide of Trade Unionism: Mapping Industrial Politics, 1964-79'. In The High Tide of British Trade Unionism: Trade Unions and Industrial Politics, 1964-79 edited by John McIlroy, Nina Fishman and Alan Campbell 93-130. Monmouth: Merlin Press, 2007.

McMichael, Joe and Lyons, 'Irish' Jack. The Who Concert File. London, Omnibus, 1997.

Moorhouse, Geoffrey. Britain in the Sixties: The Other England. Harmondsworth; Penguin, 1964.

Music from the soundtrack of The Who film Quadrophenia. Polydor, 1979.

New Musical Express

O Lucky Man!, directed by Lindsay Anderson, Warner Bros., 1973.

Osgerby, Bill. 'Bovver Books of the 1970s: Subcultures, Crisis and 'Youth-Sploitation' Novels', Contemporary British History, 26, 3 (2012) 299-331.

Pitt, Malcolm. The World on Our Backs: the Kent Miners and the 1972 Miners' Strike. London: Lawrence and Wishart, 1979.

Playfair, Guy Lyon. This House Is Haunted: The True Story of the Enfield Poltergeist. London: White Crow Books, 2011.

Powell, David. The Power Game: The Struggle for Coal. London: Duckworth, 1993.

Privilege, directed by Peter Watkins, Universal Pictures, 1967.

Quadrophenia, directed by Franc Roddam, The Who Films, 1979.

Quadrophenia: Can You See The Real Me?, directed by Matt O'Casey, BBC, 2012.

Repsch, John. The Legendary Joe Meek: The Telstar Man. London: Cherry Red Books, 1989. Reynolds, Simon. Shock and Awe: Glam Rock and its Legacy. London: Faber and Faber 2016.

Robins, David and Cohen, Philip. Knuckle Sandwich: Growing Up in the Working-class City. Harmondsworth: Penguin, 1978.

Robinson, Lucy. Gay Men and the Left in Post-war Britain: How the Personal got Political. Manchester: Manchester University Press, 2011.

Rock Around the Clock, directed by Fred F. Sears, Columbia Pictures, 1956.

Russell, Ethan. Dear Mr Fantasy. Diary of A Decade: Our Time and Rock 'n' Roll. Boston: Houghton Mifflin Company, 1985.

Sampson, Anthony. The Anatomy of Britain. London: Hodder and Stoughton, 1962.

Sandbrook, Dominic. State of Emergency: The Way We Were, 1970-1974. London: Allen Lane, 2010.

Sargeant, Mark. 'Looking back with Irish Jack', Scootering, 163, (September 1999).

Savage, Jon. England's Dreaming: Sex Pistols and Punk Rock. London: Faber and Faber, 1991.

Scala, Mim. Diary of a Teddy Boy: A Memoir of the Long Sixties. London: Headline, 2000.

Shepherd, John. Crisis? What Crisis? The Callaghan Government and the British Winter of Discontent. Manchester: Manchester University Press, 2013.

Sillitoe, Alan. Saturday Night and Sunday Morning, London: W.H. Allen 1958. 
Taylor, Andrew. The NUM and British Politics Volume 2: 1969-1995. Aldershot: Ashgate, 2005.

The Leather Boys, directed by Sidney J. Furie, British Lion, 1964.

The Who, Quadrophenia. Track Records, 1973.

The Who: Quadrophenia Live in London, directed by Chris Rule, UMC, 2014.

Tommy and Quadrophenia Live, directed by Aubrey Powell and Roger Daltrey, Rhino, 2005.

Townshend, Pete. Quadrophenia: The Director's Cut. UMC, 2011, CD.

Townshend, Pete. Who I Am. London: Harper Collins, 2012.

Turner, Alwyn W. Crisis? What Crisis? Britain in the 1970s. London: Aurum Press, 2008.

Unterberger, Ritchie. Won't Get Fooled Again: The Who from Lifehouse to Quadrophenia. London: Jawbone Press, 2011.

Waller, Robert J. The Almanac of British Politics. London: Routledge, 1983.

We Are The Lambeth Boys, directed by Karel Reisz, Graphic Films, 1959.

Weight, Richard. Mod: A Very British Style. London: The Bodley Head, 2013.

Wells, Simon. Inside The Making of Britain's Greatest Youth Film: Quadrophenia A Way of Life. London: Countdown Books, 2014.

Wharton, Gary. Chasing the Wind: A Quadrophenia Anthology. Somerset: Lushington Publishing, 2002.

Wilkerson, Mark. Who Are You. The Life of Pete Townshend. A Biography. London: Omnibus Press, 2009.

Wilky, Pete and Hellier, John. I'm the Face: Pete Meaden. Griffiths Books, 2016.

Wood, James. 'The Kids Are Alright', The Guardian, 30 May 2009.

Young, Michael and Willmott, Peter. Family and Kinship in East London. Harmondsworth: Penguin, 1957. 